\title{
Intellectual Nature of Law in the Basic Concepts of Understanding Law
}

\author{
ALEKSEI A. KOSYKH \\ Academy of Management of the Ministry of Internal Affairs of the Russian \\ Federation, Moscow, Russian Federation \\ ORCID: https://orcid.org/0000-0002-3563-6848, e-mail: lexovip36@mail.ru
}

\begin{abstract}
Introduction: formation of legal norms and their transformation, creation of the legal system, specialization and sectoral differentiation of legal norms indicate constant qualitative, intellectually grounded development of law. In the article the author analyzes basic concepts of understanding law (natural, historical, psychological, normative, Marxist, of anthropological approach) in order to determine the essence (nature) of law. The study of essential foundations of law is a fundamental task not only for the theory of law and state, but also for other sciences (philosophy of law, sociology of law, history of legal doctrines). The purpose of the work is to study an intellectual nature of law on the basis of analysis of various concepts of understanding law. Methods: the author's key conclusions and findings are based on the use of materialistic dialectics in comparative legal, sociological and historical methods. Discussions: it is noteworthy that in each concept of understanding law, intelligence (mind, reason, common sense) is considered by scientists as an integral element of the process of legal education. Conclusions: taking into account the stated above, the author proposes to consider law within the framework of an anthropological approach as a result of human intellectual activity not only by its origin, but also by its essential basis, its nature. The author puts forward the thesis that law is the result of intelligence-based thinking activity of a person and suggests the author's definition of law.

Ke y w or d s : law, essence of law, reason, intelligence, concept of understanding law.

12.00.01 - Theory and history of the law and state; history of the law and state studies.

For citation: Kosykh A.A. Intellectual nature of law in the basic concepts of understanding law. Penitentiary Science, 2021, vol. 15, no. 4(56), pp. 835-843. DOI 10.46741/2686-97642021-15-4-835-843.
\end{abstract}

\section{Introduction}

The videoconference "ArtificiallntelligenceJourney" conducted in December 2020 ("Al Journey 2020") was devoted to the use of artificial intelligence. While discussing a topic "Artificial intelligence is a key technology of the 21st century", scientists noted that by 2025 there would have been more than 40 billion intelligent devices in the world, of which $90 \%$ would have had "smart functions with elements of artificial intelligence" [14]. In this regard, the following question has arisen. Will law preserve the intellectual potential developed over the centuries and what will its share be in the law of future? Is law a product of the intellectual sphere of human activity? In order to give answers to these questions, it is necessary to analyze the nature, understand the essence and content of law in the context of intelligence and intellectual activity.

The question of determining the essence and content of law is, perhaps, one of the fundamental for the entire theory of law. The essence and content of law is considered in philosophy of law; in fact, it does not simplify, but, on the contrary, to some extent complicates the solution of many problems, since philosophy does not give unambiguous answers to many questions, but calls for their comprehension. This is probably why Cicero called philosophy the science of wisdom ("philosophy is the love of wisdom").

It is worth noting that the concepts of "essence" and "content" are not identical. The 
category "essence" reveals nature of the phenomenon and its purpose, defines features and properties. The essence is unchangeable, as otherwise the phenomenon itself will change. The essence of the phenomenon is expressed in its functions, that is, key activity areas (or activity itself). The category "content" is dialectically related to the category "form", acts as its paired category. If the form can be defined as external expression of something, an object or phenomenon, then the content is "the totality of those elements or processes that form the basis of objects and cause the existence, development and change of forms" [34, p. 463].

V.A. Tolstik and N.A. Trusov draw attention to the need to distinguish between the concepts of "essence of law" and "content of law", noting that the identification of these concepts is a methodological error, since violation of formal logic rules involves doubling of the conceptual apparatus. The scientists define the essence of law as the "main internal, relatively stable qualitative basis of law, which reflects its true nature and purpose in society" [32, p. 6]. In turn, the representatives of the Nizhny Novgorod law school define the content of law as a system of legal norms emanating from the state. Sharing this position in general, we consider precisely the essence of law, that is, its qualitative basis and true nature.

Essence of law in the basic concepts of understanding law

Political and legal schools of thought differ in the approaches to understanding the essence of law. Under the natural law theory of law origination, law is considered in terms of ideas of equality and freedom, justice, recognition of inalienable rights and freedoms of man, existence of rights reflecting the ideals of freedom and justice, which are the basis for law in its positive understanding. Thus, Hugo Grotius, dividing law into natural and will-established (which in turn he also classified into human and divine), wrote that law "has its source in will". Legislator's will is a source of domestic law, and divine will is a source of divine law. According to G. Grotius, natural law is based on "sound reason that recognize an action either morally shameful or morally necessary, depending on its conformity or contradiction to the most reasonable nature" [7].

Thomas Hobbes in his work "Leviathan or The Matter, Forme and Power of a Commonwealth Ecclesiasticall and Civil" wrote that "will of the legislator is the law ...". In turn, T. Hobbes understood natural law as "prescription, or a found by reason (emphasis added) general rule according to which a person is forbidden to do something that is harmful to his/her life or that deprives him/her of the means to preserve it ..." [4, p. 89].

Under the historical law school concept, law of every nation is an expression of historically formed common consciousness or common will of a given people. Gustav von Hugo noted that a written law arose due to the will of a sovereign, but at the same time emphasized that "not all legal provisions arose from written laws" [21, p. 44]. According to the scientist, law is "a rule established arbitrarily by the supreme power and prohibiting and prescribing something". The founder of the historical school of law, noting the awareness and recognition of legal norms as a mandatory feature of the effective operation of law, wrote that the "law used in life and recognized by judges, lawyers and legal scholars might differ from the law established by the legislator" [21, p. 46]. The successor of G. Hugo's ideas, Friedrich Karl von Savigny, described the essence of law as follows: law exists in the people's general consciousness as a popular conviction. He considered the domination of individual will as the essence of legal relations [29].

The psychological school of law considers the essence of law from the perspective of legal emotions and emotional and intellectual experiences of a person, which in one case are attributive in nature and associated with person's entitlement to something, and in the other - are imperative and arise as a result of a person's awareness of the responsibilities assumed. In pre-revolutionary Russia, this theory was developed most fundamentally in the writings of L.I. Petrazhitskii. The scientist proposed to classify law into intuitive and positive depending on the imperative-attributive experiences formed in human psyche in connection with legal facts. At the same time, the volitional side of education was not completely denied: "... in connection with the contract, before its conclusion, during the conclusion or after, there may also be a genuine expression of will" [24, p. 454].

Despite the fact that modern scientists consider L.I. Petrazhitskii's legal paradigm as sociologically oriented, having a social effect [31], and law as a socially-psychologically conditioned phenomenon [28, p. 121], the role of the intellectual principle (reason) in the formation and operation of law is repeatedly noted in the Russian-Polish scientist's works. First, legal norms were considered by L.I. Petrazhitskii as 
a "special kind of phantasms", that is, representations arising due to the work of emotional and intellectual processes of a human body. The emergence of emotions about enabling or compelling was preceded by a process of intellectual awareness ("by association of ideas or conclusions"). Second, emphasis was placed on the need to transform the doctrine of legal phenomena in the theory of law into the doctrine of emotional and intellectual elements of legal experiences. Third, the founder of the Russian psychological theory of law divided intuitive and positive law in terms of "differences of intellectual composition". It is worth noting that L.I. Petrazhitskii did not consider intuitive law as ideal, but, on the contrary, he thought that the successful existence and development of society on the basis of one intuitive right was inevitably doomed to destruction. In a number of cases, the scientist called it "unreasonable, more backward, barbaric..." than positive law. Fourth, the fact of the publication of laws without intellectual awareness, according to L.I. Petrazhitskii, does not lead to the formation of law in the human psyche. So, despite the fact that human psyche is the source of law, according to the psychological concept, human intellect or reason acts as a tool of awareness and development of psychological emotions about law.

The normative school of law defines the essence of law exclusively as a derivative of will, regardless of any external factors. Immanuel Kant, the founder of classical normativism, associated the nature of law with a "categorical imperative", a requirement of a generally binding nature. Emphasizing the importance of I. Kant's ideas for the entire theoretical and legal science, Professor I.V. Mikhailovskii noted: "Kant was the first to give a philosophical justification for the self-purpose of the individual, its moral autonomy. Only from this moment we can talk about the idea of law" [20].

According to I. Kant's doctrine, law by its nature is a complex phenomenon, which, on the one hand, acts as a means of ensuring freedom, and, on the other, as a means of restraining human freedom in order to prevent negative consequences of the manifestation of physiological instincts, vices, human nature. The idea of reason as the initial beginning of the world of ideas and the world of things is reflected in all philosophical views of I. Kant. Speaking about legal understanding, he stated: "... law is precisely such a concept of arbitrariness based on pure practical reason, subject to the laws of freedom" [12, p. 5]. As L.S. Mamut rightly notes, "reason, according to Kant, is the ability (and will) to create principles and rules of moral behavior, which contains them as an internal a priori motive" [10, p. 401]. As for cognition of many phenomena, I. Kant contrasted intellectual and emotional or sensual in the context of law: for instance, he considered legal relations absolutely intellectual; possession should be realized, that is, thought of as such on the basis of an intellectual attitude to the subject, and not on the basis of feelings; commission of legally significant acts (acquisition, possession, use) is based on the will of interested subjects, which comes from reason; only "rational concepts" can be considered as legal, etc.

The German philosopher considered natural law exclusively as cognizable by reason (emphasis added) of every person, and state law is something that is in consciousness and is based on a priori principles. In general, according to I.Kant, "law does not appear, its concept is contained in mind and represents a (moral) property of actions inherent in themselves" [11, p.71].

Hans Kelsen tried to separate legal understanding of law from related sciences, such as psychology, philosophy, and sociology, to avoid "methodological syncretism". He described his theory of law as "pure", as it was about "jurisprudence, but not the politics of law" [13, p. 10]. According to $\mathrm{G}$. Kelsen, law is a system of norms regulating human behavior, which are "oughtness" in their content. The famous philosopher considered the concept of "oughtness" much broader than simple duty: it combined the concepts of "must", "can" and "is entitled to". G. Kelsen contradicts "oughtness", that is, what is enshrined in the norms of law (what ought to be), to "isness", that is, what really is. The ability to determine the degree of conformity of "isness" to "oughtness" is assigned to human consciousness. Due to the mental process of comparing real events with norms of the Civil, Criminal, Criminal Procedure Code or the Constitution they become legitimate. According to G. Kelsen, "the content of "oughtness", that is what a positive moral or legal order dictates, is determined by acts of will, and only then cognized" [13, p. 15]. At the same time, the Austrian scientist stressed that the rule of law could be the result of cognition, and not just person's will. In this case, this is not a positive norm, since it is not put into effect, but a mental prerequisite.

Herbert Hart is a representative of the neopositivist trend in understanding law, who has become known as the creator of the linguistic 
theory of law. The English philosopher G. Hart generally shared Kelsen's concept of understanding law. According to K.G. Prokof'ev and D.V. Shkrum, the "stumbling block" of the theories of G. Kelsen and G. Hart was the question of the nature of the "basic norm": G. Kelsen's theory justified the a priori nature of the "basic norm", and G. Hart insisted on the empirical nature of normative facts [25, p. 192]. For G. Hart the essence of law consists in the unity of primary rules, which are binding, and secondary rules - those of change, recognition and trial. Having developed a formula of primary and secondary norms of law, as well as primary and secondary norms of morality, G. Hart draws a line between them: "the statement that law should correspond to morality in some more far-reaching respect ... needs a very serious verification" [35, p. 204]. At the same time, law and morality in the theory of G. Hart are interconnected by the requirement of justice. The intellectual principle in understanding law is also disclosed in the doctrine: the principles of true morality and justice can only be cognized by human mind; human mind is able to give a critical assessment of law and prove its justice or injustice; "reason" itself "requires voluntary cooperation in the system of coercion" [35, p. 200].

Besides, it is worth mentioning perhaps the most influential philosophical school of the twentieth century - the Marxist theory of law. The "representatives" of this direction define law as will of the ruling class raised into law and consider it as a superstructure over the economic basis of society. The term "representatives" is marked with quotation marks for a reason. After all, such an understanding of the essence of law often did not reflect true ideas of the materialist concept, but was a distorted interpretation (especially in the political and legal doctrine of the Soviet period) of the teachings of K. Marx and F. Engels. And this is quite understandable. To criticize political and legal ideas of Marxism-Leninism in the Soviet period was apolitical, if not illegal, therefore, the perception and misunderstanding of K. Marx and F. Engels' ideas was expounded eclectically by some scientists in the scientific works of others without conducting a detailed, comprehensive and critical analysis. As a result, the essence and content of many concepts remained distorted and were conveyed to the reader even in more distorted way.

Here are a few statements of Soviet scientists. A.Y. Vyshinskii was one of the first to de- fine law as a "set of rules (norms) of conduct established or sanctioned by the Soviet socialist state, expressing will of the Soviet people..." [22, p. 183] during the 1st Meeting of Law Researchers in 1938. The stated approach to understanding law became to some extent a "standard" for the entire theoretical and legal science and was recognized by many leading legal theorists. So, O.S. Ioffe and M.D. Shargorodskii studied law on the basis of the "assumptions that the general definition of the concept of law given in 1938" [9, p. 59]; N.G. Aleksandrov described the interpretation of law put forward by A.Ya. Vyshinskii as "unequivocally correct" [1, p. 204]; the definition of law suggested by G.I. Fed'kin was considered a "new edition of Vyshinskii's definition" [5, p. 19]. A.A. Gordienko, though criticizing A.Ya. Vyshinskii's teaching (in his work "Essence of Soviet law and its role in socialist society" he called the definition proposed by A.Ya. Vyshinskii imposed and containing obvious vices), also considered law as "state will of the working class raised to the status of law and the workers led by it", and essence of law - as the "objective content of state will" [5, p. 23].

In the famous "Manifesto of the Communist Party" by K. Marx and F. Engels law is defined as "the will of your class (emphasis added) raised to the status of law, the will whose content is determined by the material conditions of life of your class" [36, p. 42]. However, here the famous philosophers are talking about bourgeois law, that is, about the law that is exploitative, the law that is in the bourgeois' pocket, the law that needs to be fought. V.M. Syrykh, describing the materialist theory of law as a falsified Soviet legal science, writes: "K. Marx and F. Engels, contrary to the claims of Soviet authors, did not say or write that the state will of the economically and politically ruling class is the essence of law, and state coercion is its main distinguishing feature" [30, p. 14]. And indeed, K. Marx mentioned in the "Critique of Political Economy" in 1959: "they (legal relations) are rooted in material life relations, the totality of which Hegel, following the example of English and French writers of the 18th century, calls "civil society" ..." [18, p. 6]. Thus, material life relations, according to the teachings of $\mathrm{K}$. Marx, are the basis of legal relations, or, as scientists note, law itself.

This position can be seen in the works of the Soviet scientist A.I. Denisov. A.I. Denisov's followers note that he was an adherent of the historical and class approach. V.V. Lazarev, for 
example, spoke of A.I. Denisov as a scientist who "quite sincerely propagandized (in part of the Soviet state developed) the Marxist theory of the state" [15, p. 108]. Despite the fact that law, according to A.I. Denisov, is the will of the ruling class raised into law, the essence of law is not will (thereby criticizing the "bourgeois theorists"), but living circumstances of people. In addition, Professor A.I. Denisov considered law in an objective sense, as an act or a set of acts, and law in a subjective sense, as a competence. The ideas of rationalism can be traced in the question of understanding the essence of law: "one cannot understand law without addressing the question of freedom, will and relationship between freedom and necessity" [8, p. 299]. At the same time, will, according to the scientist, is something conscious, a result of conscious social relations, a conscious necessity or a kind of consciousness.

Returning to the ideas of K. Marx and F. Engels, it is worth noting that not only economic or volitional aspects in understanding different sides of the world structure were touched upon in the works of German philosophers. Appeal to reason (intelligence, including "universal intelligence") as a phenomenon that accompanies many aspects of social life gives reason to consider Marxism from the standpoint of rationalism. The philosophy of Marxism, having triggered rethinking of many philosophical problems, also disclosed the issue of finding balance between rational and irrational. The American historian Allan Megill in one of his works "Karl Marx: the Burden of Reason" noted: "The intent of my research is to prove that the Marx should be understood as a "rationalist" [19, p. 15]. Despite the controversial and illogical nature of some theoretical conclusions in the work of A. Megill, the sincerity and desire to prove the noted hypothesis deserve respect.

As for understanding the state and law, German philosophers' works quite often contain the ideas of rationalism expressed in such concepts as "state reason", "reason and law", "reasonable will", "reasonable law", and "moral reason". In one of the first journalistic articles "Comments on the Latest Prussian Censorship Instruction," written in 1842, K. Marx noted that "the government's mind is the only state mind" [16, p. 8]. "The Leading Article in No. 179 of the $\mathrm{K}$ Inische Zeitung" reveals that the "socio-educational role" of the state should consist in its "reasonable and social existence" [17, p. 103]. Rationalism in understanding of law in the ideas of K. Marx can be expressed by the following theses.

To begin with, the state and law are integral elements for construction and functioning of public life. At the same time, reason and society are at the heart of the emergence and construction of both the state and law. Developing this idea, N.A. Vlasenko contemplates the reasonability of the modern state and the role played by society as a fundamental element of statehood [2, p. 10].

Furthermore, the development of law and the state is determined by material economic relations of the society. Law (as well as the state) in this case acts as a way or means to ensure preservation, development and multiplication of existing ties between people. They help the society members eventually acquire something valuable, necessary, and vital.

Besides, the material economic relations that make up customary law can become acts and acquire the status of state, only if they do not contradict reason and law. Contradiction or non-contradiction to reason and law is defined as the result of consciousness or unconsciousness of the goals defined, tasks set, actions carried out. The state, according to the ideas of Marxism, "therefore acts according to conscious goals, cognized principles and according to acts that are acts not only in themselves, but also for consciousness".

And in general, it is worth noting that the revolutionary, anti-bourgeois ideas that are laid down in K. Marx and F. Engels' works were aimed at achieving the necessary level of "intellectual development of the working class".

In the presented study, it is impossible to ignore modern concepts of legal understanding, among which, within the framework of the paragraph under consideration, the integrative type of R.A. Romashov's understanding of law is of particular interest. Professor R.A. Romashov suggests considering law as a regulatory and protective system, endowing it with 2 main features: general significance and effectiveness. According to this concept, law consists of generally valid norms (rules) to ensure security, social stability and development [26]. In addition to the components of law indicated by scientists (legal doctrine, legal values, legal experience, legal tradition, legal doctrine), it seems justified to note legal beliefs and legal attitudes. Though they do not constitute law, but have an important impact on the process of its formation.

The anthropological concept of understanding of law developed by V.I. Pavlov is of scien- 
tific interest. In our opinion, it has a completely non-standard, but methodologically sound approach to understanding law and its essence, as well as comprehending the place and role of a person in the legal system within the framework of the concept of "man-in-law". First of all, our attention is drawn to the fact that Belarusian scientist denies classical concepts of understanding the essential nature of law, which is expressed in norms, acts, will of the legislator or justice. The researcher believes that law does not and cannot have any substantial basis, that is, the essence as true existence of law. Law, according to V.I. Pavlov, is the essence (existence).

In terms of the proposed anthropological approach (direction under the anthropological approach), law is implemented not in the norm, but in "real, daily experience of legal existence, at the intersection of a person, norm of law and fact of legal life" [23, p. 85]. In addition, V.I. Pavlov's anthropological concept considers a person in a somewhat unusual way - in terms of the "energeticity principle", that is, as a certain set of manifestations or energies (unlike essence in classical anthropology). Drawing a parallel with understanding of man in the Orthodox tradition, human or human existence is defined as an energetic image (a center of energy). At the same time, V.I. Pavlov, sharing the stance of Kh. Yannaras, S.A. Chursanov, V.N. Losskii, emphasizes the impossibility of attributing the human personality even to such aspects of it as human nature, reason, free will, mind.

At the same time, despite the conceptual development of the theory under study there are still certain issues for scientific discussion. First, if we consider a person as a kind of "energetic image", the nature or source of this energy requires explanation, given the author's refusal to regard reason, free will or mind as such. After all, the first law of energy conservation stipulates that energy cannot come from nowhere and disappear into nowhere. In our opinion, producers of this energy may be indicated sides of human personality: reason, free will or mind. It is worth noting that in some of the above definitions of "energy", V.I. Pavlov himself suggests considering this phenomenon as the "eternally driving force of a reasonable (emphasis added) human soul" [23, p. 75]. Second, based on the proposed formulas, such as "law is existence" and "man-in-law", it is sensible to pose a question about their applicability to other social or natural world phenomena. Is it possible to analyze by analogy the emergence and existence of other social regulators: traditions, customs, and religious norms? Is it possible to use the formula "law is existence" for traditions or customs? In our opinion, the questions remain open. Third, the anthropological type of understanding of law focuses on the formation of law, taken as the "legal existence of a person-in-law". Nevertheless, the issue of understanding the causes of law emergence and development among some peoples and its absence up to the present time among others (for instance, among tribes living on the territory of modern Pakistan or Cambodia) remain unresolved within the framework of the anthropological concept. It is doubtful whether the given concept can explain the reasons for such a long absence of legal norms in antiquity.

Intellectual nature of law

Understanding of the essence and nature of law differ in various scientific schools. At the same time, in every theory intelligence (mind, reason, common sense) is considered as an integral element of the law formation process. Taking into account the above, within the framework of an anthropological approach the author proposes to consider law as a result of human intellectual activity not only by its origin, but also by its essential basis, by its nature.

The thesis concerning the intellectual nature of law is supported by the following findings. First, historical development of society involves accumulation of qualitatively new knowledge, which is the result of human intellectual activity and which drives social advancement. Law is a product of rational thinking, it is a special value indicating a social development level. Throughout history, law has absorbed all the fundamental values and moral attitudes of this society and, from a formal legal point of view, has fixed them in the norms of legislation. As N.A. Gredeskul noted, law is a wise man who "works tirelessly, striving to achieve the good that is practically possible in this hostel, who never comes to despair, because he appreciates the results that he manages to achieve with his efforts" [6, p. 54].

Second, law is addressed to a person and only to a person. Despite the fact that there are cases when inanimate objects or animals could act as a subject of law (for example, legal personality of animals is presented in the legislation of Anglo-Saxon legal system countries), they are rather exceptions to the rules, since law ultimately has its effect on a person, including in the case of these inanimate objects or animals, when a person acts as a link. Only man, unlike 
other representatives of the animal world, has the degree of intellectual abilities development necessary for law and its positive impact.

Third, the intellectual nature of law is confirmed by its constant development. The origin of legal norms, their transformation, acquisition of systemic and structural properties, formation of the legal system in its modern sense, specialization and sectoral differentiation of legal norms, emergence and differentiation of subjects and methods of legal regulation, legislative consolidation of legal norms, and enhancement of technical and legal methods and means of formulating and consolidating legal norms prove a constant qualitative, intellectually grounded development of law. It is worth adding that modern man is at an advantage, since "inheriting" all the achievements in the field of law developed by a thousand-year history. It is appropriate to quote A. Rand here: "man is the only species that can expand and transfer his/ her knowledge base from generation to generation; the amount of knowledge potentially available to man is more than any person can even begin to comprehend during one of his/ her life" [27, p. 55].

Next, the author is to substantiate the chosen title - "intellectual nature of law". Thus, it is necessary to turn to the correlation of concepts of "intelligence", "common sense", and "reason". All three concepts characterize varieties of mental activity, which consists in cognition of phenomena or objects of the surrounding world, or thinking. Explanatory dictionaries reveal the concept of intelligence as the "ability of thinking, intelligent cognition, mind, reason, common sense". For example, the philosophical dictionary reveals the concept of "intelligence" (from Lat. intellectus- cognition, understanding, common sense) as similar to the concept of "mind" in the following meanings: "ability of thinking, rational cognition, in contrast to such mental abilities as feeling, will, intuition, imagination" [33]. The study of scientific literature on the methodological aspects of relationship between intelligence, reason and common sense allows us to conclude that common sense is the initial link in cognition; it transforms thoughts, ideas and images into an identifiable model with the help of a linguistic form. Intelligence is a developed form of common sense, which combines both inductive (common sense is limited only to the inductive method of thinking) and deductive thinking. Intellectual thinking, unlike common sense, is characterized by a higher speed of mental operations; it also uses such irrational forms of thinking as intuition, foresight, imagination. As for reason or rational thinking, it should be defined as the highest thinking ability of a person. Reason as opposed to common sense, according to I. Kant, "retains only absolute totality in the application of rational concepts and strives to bring the synthetic unity, which is conceived in categories, to the absolutely unconditional" [11].

Acknowledging the works of philosophers and legal theorists of the past, it is worth recognizing that reasonable thinking in the context of understanding the nature and essence of law, as the highest manifestation of thinking abilities of the human body, was not accidental. It was caused by the desire to absolutize and give an unconditional character to law as the greatest achievement of human (namely human) progress. However, if law were a product exclusively of logos (nous, the Word of God) without participation of human intellectual thinking, then the lag between legal regulation and technological progress would hardly be so obvious; according to some scientists, the gap can amount to 10 years. Another example is related to the endless array of additions and amendments made to the current legislation, indicating low quality, haste in the adoption of laws, lack of conceptuality in planning and forecasting legal regulation results. There are many examples related to the problems of force of law. The cause of this, according to N.A. Vlasenko, lies in reason itself, which can neglect consistent patterns of law, manipulate legal mechanisms or simply "do not respect it" [3, p. 12]. And in general, it should be mentioned that reason is not an absolute quantity, it is flawed and often limited by objective and subjective factors.

\section{Conclusions}

Intelligent thinking is a unique phenomenon, an ability and at the same time a principle of human life. Only man as a rational being is able to change a surrounding reality and resist harmful influence of nature, unlike animals that adapt to their habitat. And law in this aspect is directly related to reason. Reason simultaneously acts as a) the essence of law, its source; b) the principle (reasonableness principle) underlying the system of construction, development (improvement) and functioning of legal mechanisms; c) the means underlying understanding of law and interpretation of law expressed in legal norms.

Thus, based on the analysis, the author proposes the following definition of law: this is the result of intelligence-based thinking activity of a person, expressed in the information complex 
of rules of conduct, synergistically organized into the orderly system. According to the given definition, the features of law are as such: consistency and intellectual derivativeness. Consistency should be understood as an ordered system, united by the presence of internal and external relations, a set of norms (rules of conduct). Internal consistency involves the pres- ence of properties of integrity, self-regulation, continuity and integration of the legal system. External consistency implies the interaction of the legal system with other regulators of public behavior. Intellectual derivativeness is characteristic of the following: law is the result of intelligence-based thinking activity of a person.

\section{REFERENCES}

1. Aleksandrov N.G. Pravo i zakonnost' v period razvernutogo stroitel'stva kommunizma [Law and legality during the period of extensive construction of communism]. Moscow: Gosyurizdat, 1961. $271 \mathrm{p}$.

2. Vlasenko N.A. Methodological problems of the modern theory of law. Zhurnal rossiiskogo prava=Journal of Russian Law, 2019, vol. 268, no. 4, pp. 5-19. (In Russ.).

3. Vlasenko N.A. Razumnost' i opredelennost' v pravovom regulirovanii [Reasonableness and certainty in legal regulation]. Moscow: Institut zakonodatel'stva i sravnitel'nogo pravovedeniya pri Pravitel'stve Rossiiskoi Federatsii: INFRA-M, 2014. $157 \mathrm{p}$.

4. Gobbs T. Leviafan, ili materiya, forma i vlast' gosudarstva tserkovnogo i grazhdanskogo [Leviathan or the matter, forme and power of a commonwealth ecclesiasticall and civil]. P. 89. Available at: http://lib.ru/FILOSOF/GOBBS/leviafan.txt (accessed February 15, 2021)

5. Gordienko A.A. Sushchnost' sovetskogo prava i ego rol' v sotsialisticheskom obshchestve [Essence of Soviet law and its role in socialist society]. Tashkent: Fan, 1967. $147 \mathrm{p}$.

6. Gredeskul N.A. K ucheniyu ob osushchestvlenii prava. Intellektual'nyi protsess, trebuyushchii dlya osushchestvleniya prava [To the doctrine of the exercise of law. Intellectual process that requires the exercise of law]. Kharkov: tip. A. Darre, 1900. 235 p.

7. Grotius G. O prave voiny i mira. Kniga pervaya. [On the law of war and peace]. Available at: https://www.civisbook.ru/ files/File/Groziy_Kn1.pdf (accessed February 15, 2021)

8. Denisov A.I. Teoriya gosudarstva i prava [Theory of the state and law]. Moscow: Yuridicheskoe izdatel'stvo Ministerstva yustitsii SSSR, 1948. $532 \mathrm{p}$.

9. Ioffe O.S., Shargorodskii M.D. Voprosy teorii prava [Law theory issues]. Moscow: Gosyurizdat, 1962. 381 p.

10. Istoriya politicheskikh i pravovykh uchenii: uchebnik dlya vuzov [History of political and legal doctrines: textbook for universities]. Ed by V.S. Nersesyants. Moscow: Izdatel'skaya gruppa NORMA-INFRA-M, 2000. 736 p.

11. Kant I. Kritika chistogo razuma [Critique of pure reason]. Available at: https://ebooks-free.net/kniga/kritika-chistogorazuma.html (accessed March 4, 2021).

12. Kant I. Groundwork of the metaphysics of morals. Part 1. Grazhdanskoe obshchestvo v Rossii : nauchnaya elektronnaya biblioteka [Civil Society in Russia : Scientific Electronic Library]. Available at: https://www.civisbook.ru/files/File/Kant Metaphisika_2.pdf (accessed March 4, 2021).

13. Kelzen G. Chistoe uchenie o prave [Pure theory of law]. Saint-Petersburg: OOO Izdatel'skii Dom "Alef-Press", 2015. $542 \mathrm{p}$.

14. Conference on Artificial Intelligence. Ofitsial'nyi sait Prezidenta Rossii. [Official web-site of Russian President]. Available at: http://www.kremlin.ru/events/president/news/64545 (accessed February 15, 2021).

15. Krotkova N.V. General theory of law: history and current state. the 110th anniversary of the birth of A. I. Denisov (19061984). Gosudarstvo i pravo=State and Law, 2017, no. 4, pp. 107-125. (In Russ.).

16. Marx K. Comments on the latest Prussian Censorship Instruction. Marxists Internet Archive. Available at: https://www. marxists.org/russkij/marx/cw/t01.pdf (accessed March 4, 2021).

17. Marx K. The Leading article in No. 179 of the K Inische Zeitung". Marxists Internet Archive. Available at: https://www. marxists.org/russkij/marx/cw/t01.pdf (accessed March 4, 2021).

18. Marx K., Engels F. Sochineniya. T. XII. Ch. 1. [Essays]. Vol.12. Part 1. Ed. by V. Adoratskii. Moscow: Partizdat TsK VKP(b), 1935. 603 p.

19. Megill A. Karl Marks: bremya razuma [Karl Marx: the burden of reason]. Translated from English. Moscow: Kanon +, 2011. 335 p.

20. Mikhailovskii I.V. Ocherki filosofii prava. T. 1 [Essays on the Philosophy of Law. Vol. 1]. Tomsk, 1914. 632 p.

21. Nemetskaya istoricheskaya shkola prava [German historical school of law]. Chelyabinsk, 2010. 528 p.

22. Osnovnye zadachi nauki sovetskogo sotsialisticheskogo prava: doklad A. Ya. Vyshinskogo, preniya i zaklyuchitel'noe slovo na I soveshchanii po voprosam nauki sovetskogo gosudarstva i prava (16-19 iyulya $1938 \mathrm{~g}$.) [Key tasks of the science of Soviet socialist law: A.Ya. Vyshinsky's report, debates and closing remarks at the First meeting on the science of the Soviet state and law (July 16-19, 1938)]. Moscow : Yurizdat, 1938. 192 p.

23. Pavlov V.I. On the question of the anthropological type of understanding law. Pravovedenie=Understanding Law, 2015, vol. 321, no. 4, pp. 71-97. (In Russ.).

24. Petrazhitskii L.I. Teoriya prava i gosudarstva v svyazi s teoriei nravstvennosti [Theory of law and the state in connection with the theory of morality]. Vol. 2Saint-Petersburg, 1910. 758 p.

25. Prokof'ev K.G., Shkrum D.V. G. Kelsen and G. Hart on the regulatory nature of the means of legal and moral regulation of social processes. Yuridicheskaya nauka: istoriya i sovremennost'=Legal Science: History and the Presence, 2019, no. 9, pp. 188-195. (In Russ.).

26. Romashov R.A. Realistic positivism: integrative type of modern understanding of law. Izvestiya vysshikh uchebnykh zavedenii. Pravovedenie= Proceedings of Higher Educational Institutions. Pravovedenie, 2005, vol. 258, no. 1, pp. 4-11. (In Russ.).

30. Rusakov V.M., Rusakova O.F. Problem and categories of rational and irrational in Classical Marxism. Diskursologiya: metodologiya, teoriya, praktika= Discoursology: methodology, theory, practice, 2018, no. 11, pp. 190-222. (In Russ.). 
27. Rand A. Dobrodetel' egoizma [The Virtue of Selfishness]. Moscow: Al'pina Pablisher, 2018. 267 p.

28. Savenkov A.N., Gorban' V.S. L.I. Petrazhitsky as a sociologist of law. Sotsiologicheskie issledovaniya=Sociological Studies, 2019, no. 3, pp. 118-128. (In Russ.).

29. Savigny F.C. Sistema sovremennogo rimskogo prava [System of the Modern Roman Law]. Vol. 1. Translated from German by G. Zhigulin. Edited by O. Kutateladze, V. Zubary. Moscow: Statut, 2011. 510 p.

30. Syrykh V.M. Materialisticheskaya teoriya prava: Izbrannoe [Materialistic theory of law: selected] Moscow: RAP, 2011. $1259 \mathrm{p}$.

31. Timoshina E.V. Teoriya i sotsiologiya prava L.I. Petrazhitskogo v kontekste klassicheskogo i postklassicheskogopravoponimaniya: diss. ... d-ra yurid. nauk [Theory and Sociology of Law by L. I. Petrazhitskii in the context of classical and postclassical understanding of law: of Doctor of Sciences (Law) dissertation]. Moscow, 2013. 556 p.

32. Tolstik V.A., Trusov N.A. The notion of the content of law. Gosudarstvo i pravo=State and Law, 2014, no. 6, pp. 5-13. (In Russ.).

33. Filosofskaya entsiklopediya [Philosophical encyclopedia]. Available at: https://dic.academic.ru/dic.nsf/enc_philosophy/2361 (accessed March 20, 2021)

34. Filosofskii slovar' [Philosophical dictionary]. Ed. by M.M. Rozental' and P.F. Yudin. M., 1963. 544 s.

35. Hart H. L. A. Ponyatie prava [The Concept of law]. Ed. by E.V. Afonasin and S.V. Moiseev. Saint-Petersburg: Izd-vo S.Peterb. un-ta, 2007. $302 \mathrm{p}$.

36. Engels F., Marx K. Manifesto of the Communist Party. Sotsialisticheskaya Al'ternativa: sait [Sociological alternative: website]. Available at: https://socialist.news/pic/truestory/marx-permanent-revolution/communist-manifesto.pdf (accessed March 4, 2021).

\section{INFORMATION ABOUT THE AUTHOR}

ALEKSEI A. KOSYKH - Associate Professor of the Department for State and Legal Disciplines of the Academy of Management of the Ministry of Internal Affairs of the Russian Federation, Moscow, Russian Federation, Candidate of Sciences (Law), Associate Professor, ORCID: https://orcid.org/0000-0002-3563-6848, e-mail: lexovip36@mail.ru 